\title{
Identification of Delta-Aminolevulinic Acid Dehydratase (ALAD) Gene Polymorphism in Students of Elementary School in Kalideres, Jakarta
}

\author{
Annisa Firdausi, Rini Puspitaningrum, \\ Nurmasari Sartono, Afifah Izzati \\ Department of Biology, Faculty of Mathematics and Natural \\ Science, Jakarta State University \\ Jakarta, Indonesia \\ firdausi.annisa12@gmail.com
}

\author{
Chris Adhiyanto \\ Faculty of Medicine and Health Sciences, \\ Syarif Hidayatullah State Islamic University, \\ Jakarta, Indonesia \\ chrisbiomed@uinjkt.ac.id
}

\begin{abstract}
Polymorphism in ALAD genes is form of adaptation mechanism environment changes due to pollutants $\mathrm{Pb}$ (Lead) and have an impact on the health risks. Accumulation of $\mathrm{Pb}$ in the lowest air pollutants may be a risk to children's health. Children with height range between $100-140 \mathrm{~cm}(6$ to 9 years old) may have risks being exposed to $\mathrm{Pb}$. Particulates $\mathrm{Pb}$ are found in \pm 1 meter above ground. The study was done to determine frequencies of genetic polymorphisms ALAD in population students of elementary school in Kalideres, Jakarta. The method used in this study was a descriptive method with laboratory test techniques using PCR-ARMS (Amplification Refractory Mutation System) technique and the completion of questionnaires by the parents for respondent characteristics. The samples were 60 students who were $51.7 \%$ were ALAD wildtypes, $48.3 \%$ heterozygotic genotypes, and no mutants were found in the population of elementary school children in Kalideres, Jakarta. This study is necessary to identify the individual's genetic susceptibility mainly in polymorphism ALAD gene.
\end{abstract}

Keywords-Lead; Buccal mucosa cells; PCR-ARMS; Wildtype; Heterozigote

\section{INTRODUCTION}

Polymorphism in the $A L A D$ gene is an indication of the occurrence of an adaptation mechanism to changes in the environment, especially that caused by $\mathrm{Pb}$. According to [9], individuals with the ALAD-2 allele have a protective mechanism against $\mathrm{Pb}$, unlike that wit the ALAD-1 allele. This was proven by the fact that individuals with the ALAD-2 allele tended to bind $\mathrm{Pb}$ more strongly so that the $\mathrm{Pb}$ was within the blood compartment. This was very different from individuals who had the ALAD-1 allele who tended to incorporate $\mathrm{Pb}$ to bones, blood, and brain because the bond with $\mathrm{Pb}$ was relatively weak compared to individuals with the ALAD-2 allele. This study is necessary to identify the individual's genetic susceptibility mainly in polymorphism ALAD gene.
Identification of the polymorphism could be collected from peripheral blood, hair follicles, saliva, and buccal mucosa cells [13]. In this study used buccal mucosa cells with gargling technique as source of DNA. This method a non-invasive sampling DNA technique because participants are elementary school children. Children with height range between $100-$ $140 \mathrm{~cm}$ (6 to 9 years old) may have risks being exposed to $\mathrm{Pb}$. Particulates $\mathrm{Pb}$ are found in \pm 1 meter above ground. The used buccal mucosa has produced similar concentration from blood genomic DNA [4].

The pollutant $\mathrm{Pb}$ that has been absorbed into the body can be minimized by the ALAD enzyme. The ALAD enzyme is an enzyme that plays a role in the heme biosynthesis pathway which catalyzes the levulinate amino acid (ALA) molecule into monopyrrol porphobilinogen [1]. The ALAD enzyme can create a stronger bond with $\mathrm{Pb}$ based on the allele that codes this enzyme. The differences in the alleles were discovered in the first study who found that there was polymorphism in the ALAD gene, producing 2 alleles, namely ALAD-1 and ALAD-2 [3]. Polymorphism occurred in the ALAD-2 allele where the $G$ (guanine) nucleotide base is altered into $C$ (cytosine) in the coding zone $177^{\text {th }}$ nucleotide position. The change in this nucleotide base results in a change in the amino acid synthesis, from the amino lysine to asparagine [11]. Detection polymorphism ALAD gene used PCR-ARMS that allow differentiation of ALAD gene polymorphism genotype namely the wildtype, heterozygote, and mutant.

\section{METHODOLOGY}

This study was conducted at the Laboratory of Biochemistry, Faculty of Mathematics and Natural Sciences, Jakarta State University and the Laboratory of Biochemistry, Faculty of Medicine and Health Sciences, Syarif Hidayatullah Islamic State University. The study protocol had received approval from the Medical Research Ethnics Commision, Faculty of Medicine, University of Indonesia. This study was designed a descriptive method. The parents signed an 
informed consent form and filled listing the child's personal information. After receiving consent, the participants voluntary gargling using physiological saline for 40-60 seconds. Participants in this study consist of 23 boys and 37 girls (60 elementary school childrens) following criteria have lived in the area of study for the past years, aged 6-9 years and do not have hereditary blood abnormalities. DNA was isolated from the buccal mucosa cells using the Phenol Chloroform Isoamyl Alcohol (PCI) DNA extraction method.

The forward ALAD primer was F 5'-GCCTC AGTCTTCCCTCCTATTTAGT-3'and the ALAD reverse primer R 5'-TCCCTTCTTAGCCCTTCCTTTGATT-3'[12]. The concentration and temperature used for PCR were already the results of an optimation. The PCR product was 306bp. The results of the DNA isolation and amplification were analyzed quantitatively using electrophoresis with $1.5 \%$ agarose gel. The electrophoresis lasted for 30 minutes with a potential difference of $100 \mathrm{~V}$ in buffer TAE. Next, the PCR-ARMS was conducted to detect the ALAD gene polymorphism. The PCR product was diluted using SDW for the DNA template during the PCR-ARMS phase by adding $1 \mu \mathrm{l}$ of the PCR product to $99 \mu 1$ of SDW. The PCR-ARMS product was then put through electrophoresis by placing the normal primer and mutant primer in a row. ThePCR product was along 168bp, then identification of the ALAD gene polymorphism genotype was done. A sample is declared to have a wildtype genotype if a single band is formed in the normal primer well. A sample is declared to have a mutant genotype is a single band is formed in the mutant primer well. A sample is declared to have a heterozygotic genotype if two bands are formed in the normal primer well and the mutant primer well.

\section{RESULT AND DISCUSSION}

Individuals could have genetic susceptibility to pollutant exposure, one of them is the ALAD gene polymorphism [9]. Polymorphism occurs in the ALAD-2 allele where the $G$ (guanine) base nucleotide is changed to $\mathrm{C}$ (cytosine) at the 177th nucleotide position in the coding zone. Polymorphism occurs exactly in the fourth exon in the nucleotide base which codes the amino acid lysine (AAG) to asparagine [11]. Enzyme biosynthesis is under the control of a gene that is related to the nucleotide base arrangement in the nucleic acid (DNA) [14]. If there is a change in one base, it will result in an amino acid that is different in its physical and chemical characteristics, altering the protein expression.

The results of the PCR-ARMS presented in Figure 1 show a positive band signifying a positive band for ALAD gene polymorphism at $168 \mathrm{bp}$ in line with the study [12]. There is a band in the column using the normal primer, the sample has a wildtype genotype as demonstrated by sample no.A21 (Column 2). There is a band in both columns, the sample is heterozygotic as presented by sample no.A29 (Column 3 and 4). Genotypes could be identified through bands because the primers were designed specifically in the sequence that experienced a mutation and vice versa [5]. All samples were identified using the PCR-ARMS technique.

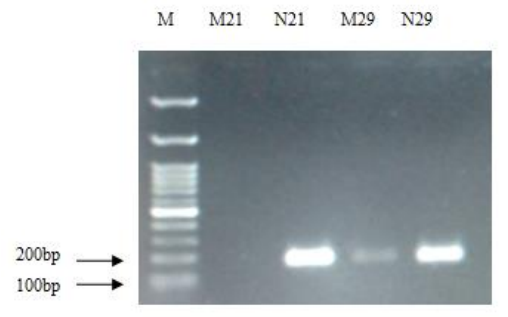

Fig. 1. The PCR phase 2 in the $1.5 \%$ agarose gel electrophoresis. $\mathrm{M}$ is the Geneaid Ladder 100bp Cat.DL007 DNA marker. Column 1 and 3 used the mutant primer (sample no. A33), column 2 and 4 used the normal primer (sample no. A49)

TABLE I. THE RESULT OF THE ALAD GENE POLYMORPHISM GENOTYPE IN THE POPULATION OF CHILDREN IN KALIDERES, JAKARTA

\begin{tabular}{|l|c|c|}
\hline \multicolumn{1}{|c|}{ Genotype } & Frequency & Percentage (\%) \\
\hline Wildtype & 31 & 51.7 \\
\hline Heterozygote & 29 & 48.3 \\
\hline Mutant & 0 & 0 \\
\hline Total & 60 & 0 \\
\hline
\end{tabular}

Based on Table I, it was discovered that $51.7 \%$ of the population of first and second-grade students at State Elementary School Kalideres, Jakarta was wildtype individuals. In another study, it was stated that the general population in Japan from a population of 101 people, there was $16.8 \%$ with heterozygotic genotype and in a population of children in Bangladesh numbering 222 individuals, $17 \%$ had a heterozygotic genotype. The discovery of wildtype individuals in a population is still pertinent [7]. The results of that study led to the conclusion that heme biosynthesis in wildtype individuals with iron deficiency could decrease, leading to anemia. Appropriate nutritional recommendations are needed to reduce the risk in $\mathrm{Pb}$ exposure.

$\mathrm{Pb}$ exposure in Kalideres area, West Jakarta, is believed to be caused by the high number of industries, the presence of a terminal, and the densely populated areas. The sampling location was chosen based on the assumption that the concentration of the pollutant $\mathrm{Pb}$ in that area was high, even though the concentration of $\mathrm{Pb}$ in the air was not measured. The high possibility of children being exposed to $\mathrm{Pb}$ in this area is due to the fact that most children walk to school. Source of $\mathrm{Pb}$ in Jakarta is mostly vehicle emission [2]. This was supported who stated that accumulation of $\mathrm{Pb}$ in the air in small concentrations could exacerbate cellular damage in the body [6].

Polymorphism in the ALAD gene is an indication of an adaptation mechanism to changes in the environment, especially those caused by $\mathrm{Pb}$. Individuals with the ALAD-2 allele have an ability to bind the $\mathrm{Pb}$ more strongly so $\mathrm{Pb}$ stays bound to the active site of the ALAD enzyme. This condition causes further inhibition by $\mathrm{Pb}$ to the enzyme ferrochelatase so that individuals with the ALAD-2 allele have a better ability to 
utilize iron (Fe) ions in the synthesis of hemoglobin [10]. This is different from individuals with the ALAD-1 allele with $\mathrm{Fe}$ ion disturbances, causing a reduction in heme biosynthesis, leading to anemia [7]. The weaker $\mathrm{Pb}$ bond in individuals with the ALAD-1 allele leads to $\mathrm{Pb}$ inhibiting the function of the ferrochelatase enzyme (10]. Therefore, nutrition plays an important role in reducing the risk of $\mathrm{Pb}$ toxicity [7].

Polymorphism in the ALAD gene also has a negative effect in the body due to exposure to $\mathrm{Pb}$. Heterozygotic individuals experienced a decline in kidney function [10]. This was because the ALAD-2 allele has a tendency to store $\mathrm{Pb}$ in blood and soft tissues such as the kidneys and pancreas. This was indicated by the fact that heterozygotic individuals had $0.10 \mathrm{mg} / \mathrm{dL}$ higher serum creatinine than wildtype individuals. An increased serum creatinine is an indicator of kidney disorders [8]. The study revealed that the increase in $\mathrm{Pb}$ in the blood of heterozygotic ALAD gene individuals causes hypertension [10].

The frequency of polymorphism in ALAD genes in the population of 60 elementary school students Kalideres, Jakarta wildtype individuals $51.7 \%$, heterozygotic individuals $48.3 \%$, and no mutants were found. Further research needs to be done with larger sample populations so that discovered mapping broader ALAD gene polymorphisms and more detailed screening in children over 9 years of age.

\section{ACKNOWLEDGMENT}

Acknowledgments are addressed to Sukoyo, S.Pd As Principal and teacher also respondents in this research. Fita Purnama Sari, Amd.Kep and Mindasari, Amd.Kep who has helped researchers in the research sampling process and Mella Ferania, S. Si who has provided advice and direction in the research process.

\section{REFERENCES}

[1] Ajioka, Richard S., Phillips, John D., Kushner, James P. 2006. Review Biosynthesis of heme in mammals. Biochem et Biophysic Act 1763 (2006): 723-736.
[2] Albalak R, Noonan G, Buchanan S, Flanders WD, Crawford CG. 2003. Blood lead and risk factor for lead poisoning among children in Jakarta, Indonesia. The Science of the Total Environment : 75-85.

[3] Battistuzzi G, Petrucci R, Silvagni L, Urbani FR, Caiola S. 1981. 5Aminolevulinate dehydrase: a new genetic polymorphism in man. J. Ann Hum Genet 45:223-229.

[4] Ghatak, Souvik, Muthukumaran, Rajendra Bose, Nachimuthu, Senthil Kumar. 2013. A Simple Method of Genomic DNA Extraction from Human Samples for PCR-RFLP Analysis. J Biomol Tech (24): 224-231.

[5] Guan, Feng., Shi, Guoqing., Wan, Pengcheng., Dai, Rong., Tang, Hong., Wang, Haixia., Luo, Yuanyuan. 2014. Development of Cost-Effective tetra-ARMS PCR for Detection of FecB Genotype in Sheep. Animal Sci Papers and Reports (32): 229-237.

[6] Kelada, Samir N., Shelton, Erin., Kaufmann, Rachel B., Khoury, Muin J. 2001. $\delta$-Aminolevulinic Acid Dehydratase Genotype and Lead Toxicity: A HuGE Review. Am J Epidemiol (154):1-13.

[7] Kim, Hee-Soon., Lee, Sung-Soo., Lee, Gap-Soo., Hwangbo, Young., Ahn, Kyu-Dong., Lee, Byung-Kok. 2004. The Protective Effect of $\delta$ Aminolevulinic Acid Dehydratase 1-2 and 2-2 Isozymes Against Blood Lead with Higher Hematologic Parameters. Env Heal Pers (112): 538541.

[8] Levey AS, Coresh J, Balk E, Kausz AT, Levin A, Steffes MW, Hogg RJ, Perrone RD, Lau J, Eknoyan G. 2003. National Kidney Foundation. National Kidney Foundation practice guidelines for chronic kidney disease: evaluation, classification, and stratification. Ann Intern Med (139): 137-147.

[9] Onalaja, Ava O. dan Claudio, Luz. 2000. "Genetic Susceptibility to Lead Poisoning”. Environ Health Perspect 108 (1): 23-28.

[10] Scinicariello F, Murray HE, Moffett DB, Abadin HG, Sexton MJ, Fowler BA.2007. Lead and delta-aminolevulinic acid dehydratase polymorphism: where does it lead? A metaanalysis. Environ Health Perspect (115) : 35-41.

[11] Wetmur, James G., Kaya, Angela H., Magdalena, Plewinska, Desnick, Robert J. 1991. Molecular Characterization of the Human $\delta$ Aminolevulinate Dehydratase 2 (ALAD2) Allele: Implications for Molecular Screening of Individuals for Genetic Susceptibility to Lead Poisoning. Am. J. Hum. Genet. (49): 757-763.

[12] Yamashiro, Yasuhiro, Hattori, Yukio, Ferania, Mella, Kentaro, Mori. 2014. UNJ Workshop of Molecular Genetics.

[13] Fatchiyah, Widyarti, Sri, Arumingtyas, Estri Laras, Rahayu, Sri. 2011. Biologi Molekuler: Prinsip Dasar Analisis. Jakarta: Penerbit Erlangga.

[14] Puspitaningrum, Rini and Adhiyanto, Chris. 2016. Enzim dan Pemanfaatannya. Bogor: Penerbit Ghalia Indonesia. 